\title{
ZMIANA MYŚLENIA O PROCESIE RESOCJALIZACJI I OSOBACH NIEDOSTOSOWANYCH SPOŁECZNIE W ŚWIETLE ZMIAN PARADYGMATÓW W POLSKIEJ MYŚLI RESOCJALIZACYJNEJ. NURT „NOWEJ RESOCJALIZACJI”
}

\section{Changing of Thinking about Resocialization Process and to Social Awkwardness People in the Context of Paradigm Changing in Polish Resocialization Idea. „New Resocialization” Current}

Summary: The purpose of this article is presentation about changing of thinking about resocialization process and to social awkwardness people in the context of paradigm changing in polish resocialization idea. Author presents two currents in the resocialization area: traditional resocialization and "new resocialization” current. The consequences in this situation is methodical changes in general line with adjusted people. It is why question: „how to resocialize?" is actual too.

Keywords: resocialization process, adjusted people, paradigm, „new resocialization” current, polish resocialization idea

Paradygmat to nic innego jak pewien przyjęty sposób widzenia rzeczywistości w danej dziedzinie. Wraz z publikacją książki Struktura rewolucji naukowych Thomas Samuel Kuhn² przyczynił się do powstania klimatu kontrowersji wokół przywołanego pojęcia. Konsekwencje klimatu kontrowersji widoczne są do dziś szczególnie na gruncie nauk społecznych, w tym w pedagogice. Status

${ }^{1}$ Dr Małgorzata Michel jest adiunktem w Zakładzie Profilaktyki Społecznej i Resocjalizacji Instytutu Pedagogiki na Wydziale Filozoficznym UJ. Adres: Instytut Pedagogiki UJ, ul. Batorego 12, 31-135 Kraków; e-mail: malgorzata.michel@uj.edu.pl.

2 Thomas S. Kuhn, Struktura rewolucji naukowych (Warszawa: Wydawnictwo Aletheia 2001). 
paradygmatu w naukach pedagogicznych uzyskuje dzisiaj wiele teorii. Zwykle ich zwolennicy chcą im przyznać najwyższą rangę i uczynić je dominującymi. Tym samym paradygmatem często próbuje się nazwać sposoby działania, które w danym środowisku uważane są za powszechne i obowiązujące. Do nich należą podejścia wieloaspektowe, paradygmaty diagnostyczne czy wychowawcze. Często autorzy usytuowania konkretnej koncepcji czy podejścia w przestrzeni paradygmatów mają dobre intencje, paradygmaty wyłaniane są jednak z postulatów pedagogicznych, mających życzeniowy charakter, lub z celów, do których zmierzają twórcy i pomysłodawcy. Stąd mówi się o paradygmacie autonomii wychowanka, współpracy z rodziną czy integracji społecznej, na przykład osób niepełnosprawnych. Jednakże w gąszczu owych paradygmatów dyscypliny, jaką jest pedagogika, obecnie mamy do czynienia nawet nie tyle z wielością paradygmatów, co z paradygmatycznym chaosem.

Autorka niniejszego artykułu stawia sobie za zadanie przyjrzenie się owej wielości paradygmatycznej i w jej świetle próbę usytuowania współczesnej myśli resocjalizacyjnej w Polsce, ze szczególnym uwzględnieniem nurtu tak zwanej „nowej resocjalizacji”. Pedagogika resocjalizacyjna w chwili obecnej ma status samodzielnej dyscypliny pedagogicznej i coraz rzadziej w literaturze przypisywana jest zakresowo pedagogice specjalnej. Wciąż uznawana jest za subdyscyplinę tej ostatniej, prawdopodobnie $\mathrm{z}$ racji ujmowania osób niedostosowanych społecznie jako takich, które potrzebują czy wymagają specjalnych metod wychowawczych, metodyczno-psychologicznych i medycznych ${ }^{3}$. Od początku jednak swojego istnienia pedagogika resocjalizacyjna ma charakter i status nauki interdyscyplinarnej. W rezultacie zarówno jej podstawa teoretyczna, jak i metodyczna nie były bazami jednorodnymi metodologicznie ${ }^{4}$. Przesłanki teoretyczne pedagogika resocjalizacyjna czerpała z nauk filozoficznych, psychologicznych, socjologicznych, kryminologicznych, medycznych, próbując jednocześnie na gruncie zaadaptowanych teorii konstruować własne koncepcje wyjaśniające mechanizmy nieprzystosowania społecznego, patologii społecznych i indywidualnych oraz innych form zaburzeń w zachowaniu i funkcjonowaniu ludzi będących przedmiotem jej zainteresowania ${ }^{5}$. Podobnie sytuacja wygląda $\mathrm{z}$ wymiarem metodycznym pedagogiki resocjalizacyjnej. Jej działalność praktyczna oparta jest bowiem na współdziałaniu wielu teorii reprezentujących różne nurty i dyscypliny naukowe, takie jak psychologia, medycyna czy praca socjalna.

Wynik analizy literatury oraz debat, które od lat 90 . XX wieku odbywały się na licznych konferencjach i seminariach $\mathrm{w}$ ramach pedagogiki resocjalizacyjnej nie pozostawiają wątpliwości co do kryzysu, wyczerpania się tradycyjnego

${ }^{3}$ Maria Grzegorzewska, Pedagogika specjalna (Warszawa: Wyższa Szkoła Pedagogiki Specjalnej im. M. Grzegorzewskiej w Warszawie 1964).

${ }^{4}$ Marek Konopczyński, Pedagogika resocjalizacyjna $w$ stronę działań kreujących (Kraków: Oficyna Wydawnicza „Impuls” 2014).

${ }^{5}$ Tamże. 
paradygmatu i prób nowych uzgodnień paradygmatycznych. Wyraźnie zaznaczający się od pewnego czasu nurt myślowy w pedagogice resocjalizacyjnej domaga się w mojej opinii usytuowania paradygmatycznego. Chociaż na przykład autor koncepcji twórczej resocjalizacji Marek Konopczyński wyraźnie lokuje swoją koncepcję w konkretnym paradygmacie. Autor też zresztą poszerza pole swoich rozważań, dokonując swoistego porównania dwóch „pedagogik resocjalizacyjnych", co będzie rozpatrywane dalej. Wyraźnie zatem, szczególnie w pewnych koncepcjach, zarysowuje się kierunek rekonstrukcji paradygmatycznej z wektorem skierowanym na paradygmat humanistyczny. Paradygmatyczne dezaktualizacje dotyczą natomiast głównie biologizmu i medykalizacji, wiary w resocjalizacyjną moc i funkcję prawa, utożsamiania resocjalizacji z terapią, korektą i naprawą oraz wiary w instytucjonalne działania zmiany przestępcy na lepszego człowieka i wyprowadzenie go $\mathrm{z}$ agonii moralnej w izolacji, bez udziału społeczeństwa. Sądzę, iż warto dodać nieczęsto zaznaczany przez poszczególnych autorów czynnik, mianowicie czynnik związany z przestrzenią rozwoju duchowego człowieka. A przecież, na co wskazują liczne badania, to programy resocjalizacyjne i readaptacyjne oparte na duchowości i wartościach moralnych, jak choćby niezwykle popularny Program Dwunastu Kroków, realizowane na marginesie oficjalnego systemu lub obok niego wykazują się niezwykłą skutecznością ${ }^{6}$. Aby prześledzić zmianę myślenia o procesie resocjalizacji i osobach niedostosowanych społecznie w świetle zmian paradygmatów w polskiej myśli resocjalizacyjnej, warto powrócić na moment do samego pojęcia paradygmatu.

Thomas S. Kuhn definiował paradygmat najprościej jako zbiór pojęć i teorii tworzących podstawy danej nauki. Przy czym teorii i pojęć tworzących paradygmat raczej się nie kwestionuje, przynajmniej do czasu, kiedy paradygmat spełnia swoje funkcje i jest poznawczo twórczy, czyli innymi słowy, kiedy za jego pomocą można tworzyć teorie szczegółowe, zgodne z danymi doświadczalnymi, którymi zajmuje się nauka. Dobry paradygmat musi spełniać pewne warunki, mianowicie być spójny pod względem logicznym i pojęciowym, być prosty i zawierać jedynie te pojęcia i teorie, które dla danej nauki są rzeczywiście niezbędne, oraz dawać możliwość tworzenia teorii szczegółowych zgodnych ze znanymi faktami. Autor Struktury rewolucji naukowych koncentrował się w swoich rozważaniach na paradygmatach $w$ naukach przyrodniczych, jednakże w nauce obecna jest również dyskusja na temat paradygmatów w dyscyplinach społecznych. W nich jednocześnie mogą występować różne paradygmaty. Tym samym dochodzi do wojen paradygmatycznych, czyli wzajemnego zwalczania się uczonych z różnych obozów czy frakcji naukowych, a nawet światopoglądowych.

${ }^{6}$ Frank Riessman, David Carrol, Nowa definicja samopomocy. Polityka i praktyka (Warszawa: Państwowa Agencja Rozwiązywania Problemów Alkoholowych 2000). 
W encyklopedii pedagogicznej paradygmat rozumiany jest jako:

wzorcowa teoria $[\ldots]$ o zasadniczym znaczeniu dla danej nauki, która umożliwia badaczom określonej dziedziny przyjęcie założeń uznawanych za pewne i skupienie się na rozwiązywaniu bardziej konkretnych problemów; jest to więc całość założeń oraz kryteriów interpretacyjnych, które umożliwiają analizę i ocenę wyników badań naukowych?

\section{Dalej możemy przeczytać, iż:}

jest to rodzaj formy, która z góry organizuje sposób postrzegania i wartościowania analizowanych zjawisk. Ponieważ forma jest taka sama dla wszystkich badaczy przynależnych do danego kolektywu myślowego, bywa niedostrzegalna. Można ją zauważyć z zewnątrz, reprezentując odmienny styl myślowy.

Akceptowany stopień uzgodnień przez ogół badaczy jest o tyle istotny, iż w praktyce przekłada się lub przynajmniej powinien się przekładać na pewną konkretną wizję człowieka, koncepcję rzeczywistości i sposoby jej rozumienia. To z kolei tworzy podwaliny pod pytania: jak wychowywać? jak resocjalizować?

Pytania te, pomimo zaawansowanego rozwoju pedagogiki jako nauki, wciąż nie tracą na aktualności, przyjmując coraz to nowe oblicza. Zresztą jest to naturalna trajektoria rozwoju dyscyplin społecznych, zważywszy na ogromną dynamikę rzeczywistości i zachodzących w niej zmian na wszystkich płaszczyznach życia (społecznego, politycznego czy cywilizacyjnego) i to zarówno na poziomie światowym, jak i wewnątrz poszczególnych wspólnot politycznych, państw czy regionów lokalnych. To wymusza na pedagogice ciągłą rewizję pojęć, twierdzeń i koncepcji. Przykładem może być właśnie pedagogika resocjalizacyjna, której nie tylko obserwacja, lecz także analizy literatury każą wyciągnąć wnioski, iż na przełomie XX i XXI wieku doświadczyła wyraźnego kryzysu zmiany, co widać na przykładzie polskiej myśli resocjalizacyjnej oraz powiązanych z nią praktycznych działań w sferze instytucjonalnej. Jak pisze M. Konopczyński, wokół pedagogiki resocjalizacyjnej narosło wiele wątpliwości i nieporozumień ${ }^{9}$. Pojawiły się też liczne błędne przekonania, które można pogrupować w pewne bardzo wyraziste mity, oparte bardziej na wiedzy potocznej, niźli na dowodach naukowych. Pierwszy mit to wiara w resocjalizacyjną rolę prawa. Drugi to twierdzenie, iż terapia jest tym samym, co resocjalizacja. Wynika on z traktowania przez długi czas osoby zdemoralizowanej, jej niedostosowania społecznego i przestępczości jako formy choroby społecznej wymagającej leczenia. Ostatni mit natomiast stwierdza, iż instytucje resocjalizacyjne zmieniają przestępcę w lepszego

7 Anna Sięgień, „Paradygmat”, w: Encyklopedia pedagogiczna XXI wieku, t. 4, red. Tadeusz Pilch, (Warszawa: Wydawnictwo Akademickie Żak 2005), 36.

8 Tamże, 37.

${ }_{9}$ Konopczyński, Pedagogika resocjalizacyjna, 58. 
człowieka i są tym samym najskuteczniejszym rozwiązaniem. Wspomniane powyżej mity wynikające z rozwoju myśli resocjalizacyjnej mają swoje konsekwencje w konkretnych rozwiązaniach praktycznych. Analiza współczesnych praktyk resocjalizacyjnych, jak wnioskuje przywołany autor, wynika z przyjętych przed laty teoretycznych oraz metodycznych założeń i koncepcji pochodzących jeszcze z połowy XX wieku. Tym samym ukazuje „zakurzone” oblicze resocjalizacji ${ }^{10}$. Równolegle do wspomnianych mitów można zatem wyróżnić trzy oblicza (twarze) pedagogiki resocjalizacyjnej, są nimi: twarz Marsowa - jurydystyczna, twarz Eskulapowa - terapeutyczna oraz twarz Fortuny - nadziei na lepszą przyszłośćc ${ }^{11}$.

Opisana powyżej sytuacja zdaje się charakterystyczna dla prezentowanego przez Kuhna kryzysu w nauce. Kryzysy takie są wyzwalane w momencie, gdy uczeni uznają odkryte sprzeczności za anomalie w dopasowaniu istniejącej teorii do natury. Można by się pokusić o zmianę tego stwierdzenia celem dopasowania go do realiów nauk społecznych, mocno osadzonych w społecznej rzeczywistości, i uznać, iż kryzysy takie wyzwalane są w momencie, gdy uczeni uznają odkryte sprzeczności za anomalie $\mathrm{w}$ dopasowaniu istniejącej teorii do rzeczywistości społecznej. Wszystkie kryzysy w nauce rozwiązywane są na trzy sposoby: nauka instytucjonalna może udowodnić zdolność do objęcia kryzysowego problemu i w tym wypadku „wszystko wraca do normalności”; alternatywnie, problem pozostaje i jest zaetykietowany, postrzega się go natomiast jako wynik niemożności użycia niezbędnych przyrządów i narzędzi do rozwiązania go. Tym samym uczeni pozostawiają jego rozwiązanie przyszłym pokoleniom, wierząc w rozwój zaawansowania narzędzi. Trzecim sposobem, najrzadszym, jest sytuacja pojawienia się nowego kandydata na paradygmat, co powoduje wygenerowanie bitwy o jego uznanie. Bitwę tę Kuhn nazywa wojną paradygmatów ${ }^{12}$.

W swoich rozważaniach powrócę do książki Kuhna, w której autor zainicjował zmianę myślenia o rozwoju nauki, wprowadzając pojęcie rewolucji naukowej. Najważniejszym pojęciem i determinantem tytułowej rewolucji według cytowanego autora jest wyodrębnianie się w poszczególnych dyscyplinach nauki właściwych dla niej paradygmatów. Zanim jednak to nastąpi, mamy do czynienia $\mathrm{z}$ tak zwanym etapem przedparadygmatycznym, czyli okresem przypadkowego i chaotycznego zbierania danych oraz równoległego wykształcania się funkcjonujących i konkurencyjnych wobec siebie twierdzeń, stanowisk i teorii. $Z$ tym związane jest tworzenie różnych szkół reprezentujących konkretne koncepcje naukowe. $Z$ biegiem czasu oraz wraz z osiąganiem dojrzałości naukowej jako odpowiedź na pewne kryzysy i problemy nierozwiązane wykształcają się paradygmaty. Tym samym do rozwoju nauki dochodzi wówczas, gdy „społeczność zawodowa dokona przewartościowania

10 Tenże, Kryzys resocjalizacji czy(li) sukces działań pozornych. Refleksje wokó polskiej rzeczywistości resocjalizacyjnej (Warszawa: Wydawnictwo Pedagogium 2013), 41.

${ }_{11}$ Tamże.

${ }^{12}$ Kuhn, Struktura. 
tradycyjnych procedur doświadczalnych, kiedy zmieni bliskie jej dotychczas poglądy na budowę świata i w końcu przekształci siatkę teoretyczną, za pomocą której ujmuje świat”13. Dalej Kuhn pisze: „pozostaje też sprawą otwartą, czy którakolwiek $\mathrm{z}$ dyscyplin nauk społecznych w ogóle osiągnęła już jakiś paradygmat. Historia pokazuje, że droga do takiej jednomyślności w badaniach jest niezwykle trudna" ${ }^{14}$.

W tym kontekście wagi nabierają rozważania nad problematyką paradygmatów polskich reprezentantów pedagogiki w osobach Zbigniewa Kwiecińskiego, Bogusława Śliwerskiego, Lecha Witkowskiego, Teresy Hejnickiej-Bezwińskiej, Joanny Rutkowiak czy Krzysztofa Rubachy. Na podstawie przeglądu twórczości naukowej tych autorów Amadeusz Krause przedstawia w swojej pracy Współczesne paradygmaty pedagogiki specjalnej ${ }^{15}$ pewną wizję paradygmatu, niezbędną do zrozumienia prezentowanych treści i zagadnień z zakresu pedagogiki specjalnej. Wydaje się to o tyle istotne, że pedagogika resocjalizacyjna, będąca przedmiotem rozważań, jest również - jak już zostało wspomniane - subdyscypliną pedagogiki specjalnej.

Czytelną mapę usytuowania paradygmatów w naukach społecznych prezentuje Krzysztof Rubacha, który pisze, iż:

świat społeczny można analizować w obrębie dwóch kluczowych kategorii: człowieka jako istoty społecznej i społeczeństwa. W odniesieniu do tych kategorii przedstawiciele nauk społecznych sformułowali podstawowe pytania: Jak istnieje świat społeczny? Jaka jest natura człowieka? Jak zmienia się społeczeństwo? I właśnie odpowiedzi na te pytania stanowią przesłanki wyjaśniania zjawisk społecznych, składających się na paradygmaty nauk społecznych ${ }^{16}$.

W konsekwencji według cytowanego autora możemy mówić o czterech paradygmatach $\mathrm{w}$ naukach społecznych, są to: humanizm, strukturalizm, funkcjonalizm i interpretatywizm. Pojawiły się również warianty krytyczne i opozycyjne wobec dominujących paradygmatów, które można ująć $\mathrm{w}$ takie podejścia, jak: funkcjonalizm, humanizm, interpretatywizm i hermeneutyka. Zbigniew Kwieciński pisze, iż w wymienionej kolejności różnią się one stopniem malejącej perswazyjności, której zmniejszenie i unikanie staje się kryterium poprawności naukowej i jedynie dopuszczalnej postawy etycznej pedagoga $\mathrm{w}$ procesach wychowawczych ${ }^{17}$.

13 Tamże, okładka, 4.

14 Tamże, 41.

15 Amadeusz Krause, Współczesne paradygmaty pedagogiki specjalnej (Kraków: Oficyna Wydawnicza „Impuls” 2010).

16 Amadeusz Krause, cyt. za: Krzysztof Rubacha, „Budowanie teorii pedagogicznych”, w: $P e$ dagogika. Podręcznik akademicki, t. 1, red. Zbigniew Kwieciński, Bogusław Śliwerski, (Warszawa: Wydawnictwo PWN 2003), 60.

17 Zbigniew Kwieciński, „Mimikra czy sternik? Dramat pedagogiki w sytuacji przesilenia formacyjnego", w: tegoż, Tropy - ślady - próby. Studia i szkice z pedagogiki pogranicza (PoznańOlsztyn: Wydawnictwo Edytor 2000). 
Zbigniew Kwieciński podaje, iż paradygmat jest to „zbiór ostatecznych przesłanek w wyjaśnianiu jakiegoś obszaru rzeczywistości przyjętych w społeczności uczonych, a następnie upowszechniony jako zbiór myślenia w normalnych zbiorowościach użytkowników nauki"18. Poza wąskie rozumienie pojęcia paradygmatu można przyjąć również rozważania Bogusława Śliwerskiego, który pisze, iż

paradygmat jest [...] zestawem założeń ontologicznych dotyczących natury rzeczywistości i roli nauki, które rzutują na akceptację wyników badań w danej epoce i danym miejscu [...]. Wartości nauki nie są bowiem niezmienne. Wraz z kolejnym paradygmatem pojawiają się nowe kategorie pojęciowe, które przekształcają $\mathrm{w}$ fakt naukowy to, co dla poprzedniego paradygmatu było jakąś nieprawidłowością, anomalią̨ ${ }^{19}$.

Kontynuując myśl tego autora, można powiedzieć, iż w pedagogice mamy do czynienia z wielością paradygmatów, które jednak muszą być równouprawnione. Tym samym Śliwerski każe nam dojść do konkluzji, iż pedagogika jest nauką paradygmatyczną, w której w danym okresie po prostu dominuje jeden paradygmat. W konsekwencji paradygmaty muszą rezygnować ze swoich roszczeń do wyłączności.

Liczne też informacje związane $\mathrm{z}$ wieloparadygmatycznością pedagogiki jako nauki można znaleźć $\mathrm{w}$ pracach Lecha Witkowskiego ${ }^{20}$, czego tutaj nie będę już rozwijała. Wspomnę jedynie, iż uczony ten wyraźnie akcentuje znaczenie wizji rozwoju i tradycji dyscypliny, jaką jest pedagogika, duży nacisk kładąc na wspólnotowość badawczą jej reprezentantów. Wspólnotowość ta znajduje swoje odzwierciedlenie w takich aktach, jak rodzaj wspólnych lektur czy obowiązujący w danym kręgu kanon nauczania. Pozwala to na wskazywanie nie tylko zmiany postrzegania faktów, teorii czy badawczych strategii, lecz także na odmienność wizji całych dyscyplin, zakorzenioną w sposobach ich postrzegania i uprawiania ${ }^{21}$. Ważne jest, aby nie mylić powyższych słów z przyzwoleniem na teoriotwórczą dowolność.

Podobne konkluzje na temat wieloparadygmatyczności pedagogiki podaje Rolland Paulston, który pisząc o heterogeniczności współczesnych teorii pedagogicznych, postuluje zakończenie wojen paradygmatycznych ${ }^{22}$ na rzecz komplementarności. Konstatuje on dalej, iż być może sama dyskusja o paradygmatach pedagogiki straci z czasem sens, ponieważ to, co rozumiemy jako ogólny zbiór ostatecznych przesłanek w wyjaśnianiu jakiegoś obszaru rzeczywistości, może

18 Tamże, 47

19 Bogusław Śliwerski, Współczesna myśl pedagogiczna. Znaczenia, klasyfikacje, badania (Kraków: Oficyna Wydawnicza „Impuls” 2009), 29.

${ }^{20}$ Lech Witkowski, Edukacja i humanistyka. Nowe konteksty dla nowoczesnych nauczycieli, t. 2 (Warszawa: Instytut Badań Edukacyjnych 2007).

21 Tamże.

22 Rolland G. Paulston, „Pedagogika porównawcza jako pole nakreślenia konceptualnych map teorii i paradygmatów", w: Alternatywy myślenia o edukacji, red. Z. Kwieciński (Warszawa: Instytut Badań Edukacyjnych 2000). 
wobec rozgałęzienia teoretycznego stracić swoją jednoznaczność i przydatność paradygmatyczną. $\mathrm{W}$ zamian pozostanie płynna i zmienna konstrukcja wielu stanowisk interpretacyjnych, uzupełniających się wzajemnie bądź wchodzących ze sobą w spór czy wykluczających się. Ostatecznie podpieranie się założeniem paradygmatyczności współczesnej pedagogiki może czasem nie wystarczyć, ponieważ nie można mówić o paradygmatach, dezaktualizując ich najważniejsze cechy, zdolność ich rozumienia, opisu i interpretacji. W tym kontekście Joanna Rutkowiak pisze, iż funkcjonowanie wielu paradygmatów o równoprawnych statusach może spowodować, iż ich nosiciele mogą wybrać kilka wobec siebie zachowań: mogą zachować wzajemną zależność, mogą ze sobą konkurować, współdziałać dopełniająco lub wzajemnie przekładać treści uprawianych przez siebie paradygmatów ${ }^{23}$. Interesujące, że autorka prezentuje ciekawy projekt przekładów paradygmatycznych. Inspirując się rozważaniami Tomasza Szkudlarka o opozycyjnej subiektywności i obiektywności w pedagogice, poszukującego „trzeciej drogi”, za której główne ogniwo uważa kategorię realności² ${ }^{24}$ pisze:

przez owo przekładanie [paradygmatów - przyp. aut.] rozumiem podmiotową aktywność semantyczną, polegającą na takim modyfikowaniu znaczeń pedagogicznej wypowiedzi paradygmatycznej, jaka - mówiąc wstępnie - umożliwiłaby „użytkownikowi paradygmatu" poruszanie się między zwielokrotnionymi jakościami potencjału jego treściowej przestrzeni ${ }^{25}$.

W świetle powyższych rozważań warto jasno zaznaczyć, co mocno podkreśla Lech Witkowski, że przyjęcie założenia o wieloparadygmatyczności współczesnej pedagogiki nie upoważnia do całkowitej dowolności posługiwania się tym pojęciem i jego nadużywania. Odnosząc się bezpośrednio do koncepcji Kuhna, Witkowski pisze o sytuacji zarówno alternatywności paradygmatów, jak i o patologii niealternatywności ${ }^{26}$. Oba zjawiska szczegółowo analizuje i jak stwierdza stają się one przestrogą przed uprawianiem „indywidualizmu paradygmatycznego", a więc posługiwaniem się tymi kategoriami pojęciowymi w celu umocnienia własnych poglądów i kompetencji lub wręcz maskowaniem ich braku. Wielość interpretacji tworzy wieloparadygmatyczność, gdzie uzgodnienia nie mają wyłącznie charakteru hierarchicznego, lecz również równoległy - czasami się zwalczają, pozostając w sporze, czasami natomiast uzupełniają. Zmiana paradygmatu w naukach społecznych może zatem nastąpić bez zdefiniowanego, konkretnego

${ }^{23}$ Joanna Rutkowiak, „Wielość paradygmatów dydaktyki a wspólny mianownik realności życia. Ku pytaniom o przekłady międzyparadygmatyczne", w: Paradygmaty współczesnej dydaktyki.

${ }^{24}$ Tomasz Szkudlarek, „Obiektywizm i subiektywizm pedagogiczny a całościowe myślenie o wychowaniu", w: Pytanie-dialog-wychowanie, red. J. Rutkowiak (Warszawa: Wydawnictwo Naukowe PWN 2009).

25 Tamże, 76.

${ }^{26}$ Lech Witkowski, Między pedagogika, filozofia i kulturą. Studia, eseje, szkice, t. 3 (Warszawa: Instytut Badań Edukacyjnych 2007). 
odkrycia czy przyjętej teorii, a wynikać wyłącznie z tego, co przypisujemy na przykład dojrzałości społecznej, humanizacji życia społecznego, nowemu porządkowi, czasom, postępowi technologicznemu, zwyczajom czy kulturze. Wątpliwości mogą też dotyczyć różnych interpretacji tych samych teorii.

Jeszcze jedną istotną kwestią nad rozważaniami w związku z pojęciem zjawiska paradygmatu jest pojęcie „uspołecznienie paradygmatu”, na które uwagę zwraca Amadeusz Krause ${ }^{27}$. Przez pojęcie to autor rozumie zaakceptowanie paradygmatu przez zbiorowość, w której jest on tworzony, a której prawidłowości i znaczenia interpretuje. Na przykładzie rozwoju pedagogiki można przyjąć, że o ile powstają w niej idee wyprzedzające aktualne uzgodnienia społeczne, o tyle dopiero $\mathrm{w}$ procesie upublicznienia i społecznej weryfikacji umacnia się wiara $\mathrm{w}$ ich prawdziwość ${ }^{28}$. Rozpowszechnione przekonanie o skuteczności rozwiązywania problemów, które daje ta idea, umożliwia przekształcanie się jej w akceptowaną wiedzę paradygmatyczną. Wiedza ta ma charakter zatem nie tyle odkrywania, co społecznej zgody na aktualizację znaczeń i interpretacji.

Uspołecznienie paradygmatu zakłada swoistą przydatność paradygmatyczną dla szerszej zbiorowości, co jasno komunikuje Kwieciński, stawiając tezę o rozpowszechnieniu wzorców myślenia w zbiorowościach użytkowników nauki²9. Tym samym można mówić o odmiennym sposobie powstawania paradygmatu w naukach społecznych, a więc o procesie przekształcania wiedzy i doświadczeń społecznych w powszechną akceptację uzgodnień zarówno na gruncie dyscypliny naukowej, jak i w obszarach społecznej interpretacji. Tę siłę uzgodnienia paradygmatu cytowany już Krause nazywa „drugim życiem paradygmatu” ${ }^{30}$. Tutaj jednak, jak zaznacza autor, może się pojawić problem związany z tym, iż zmiana paradygmatyczna w nauce może się dokonać znacznie szybciej aniżeli $\mathrm{w}$ interpretacjach społecznych. Pomimo przecież wskazania nowej drogi w dyscyplinie naukowej jej wcześniejsze dokonania pozostają nienaruszone. Taki odrzucony paradygmat może długo jeszcze pozostawać w swoistej opozycji, czego przykładem są utrwalone w wyniku naukowych uzgodnień stereotypy. Jak pisze Krause, są one szczególnie widoczne na gruncie pedagogiki specjalnej. Przykładem niech będzie choćby przez lata funkcjonujący paradygmat biologiczny niepełnosprawności. Wydaje się to o tyle istotne, iż ma swoje konsekwencje w postaci istniejących przekonań o niezaradności, inności niepełnosprawnych czy konieczności izolacyjnego rehabilitowania, które w wielu społecznych obszarach funkcjonują do dziś.

Powyższe rozważania i przykłady są o tyle znaczące, że pośrednio dotyczą również pedagogiki resocjalizacyjnej. $\mathrm{W}$ ostatniej dekadzie nastąpiła wyraźna zmiana myślenia o procesie resocjalizacji i osobach niedostosowanych społecznie,

\footnotetext{
${ }^{27}$ Krause, Wspótczesne paradygmaty, 33.

28 Tamże, 33.

${ }^{29}$ Kwieciński, „Mimikra”, 53.

${ }^{30}$ Krause, Wspótczesne paradygmaty, 34.
} 
którą można rozpatrywać w świetle zmian paradygmatów w polskiej myśli resocjalizacyjnej. Oprócz tradycyjnej, klasycznej pedagogiki resocjalizacyjnej pojawił się bowiem nurt współczesnej, nieklasycznej pedagogiki resocjalizacyjnej, zwany niekiedy nurtem „nowej resocjalizacji”. Autor tego podejścia, przywoływany już Marek Konopczyński, zaczyna swoje rozważania zmierzające do przedstawienia tego nowego nurtu i porównania „dwóch pedagogik resocjalizacyjnych” od prezentacji paradygmatów istniejących w rozwoju omawianej subdyscypliny. Pisze, iż „myślenie pedagogiczne oparte jest na określonych paradygmatach rozumianych jako zbiór ogólnych przesłanek w wyjaśnianiu obszaru rzeczywistości, przyjętych przez przedstawicieli dyscypliny naukowej jako wzór ostatecznego myślenia" ${ }^{31}$. Cytowany autor wymienia przy tym cztery paradygmaty, które wywarły największy wpływ na bazę teoretyczną pedagogiki resocjalizacyjnej, a tym samym również na praktykę wychowawczą. Są to: paradygmat strukturalistyczny, funkcjonalistyczny, humanistyczny i interpretatywny. Na bazie tych paradygmatów powstały dwie tendencje budowania teorii pedagogicznych. Pierwsza $\mathrm{z}$ nich to pajdocentryzm - oparty na paradygmacie humanistycznym. Jego przeciwstawieniem jest didaskaliocentryzm, mieszczący się w paradygmacie strukturalistycznym i funkcjonalistycznym. Wspomniane paradygmaty i teorie wywarły decydujący wpływ na teoretyczną i aplikacyjną przestrzeń pedagogiki resocjalizacyjnej. Dotyczy to zarówno jej nurtu klasycznego, jak i nowych nurtów oraz poszukiwań teoretycznych uzasadnień procesu resocjalizacji.

Według Konopczyńskiego u podstaw powstania klasycznej pedagogiki resocjalizacyjnej leżały: paradygmat strukturalistyczny i funkcjonalistyczny z teoretyczną koncepcją didaskaliocentryzmu, a dominującą szeroką bazą teoretyczną i metodyczną była pedagogika neopozytywistyczna. Współczesna (nowa) pedagogika resocjalizacyjna sięga natomiast do wizji pajdocentrycznej, opartej na paradygmacie humanistycznym i interpretatywnym ${ }^{32}$. Ta zasadnicza różnica $\mathrm{w}$ teoretycznym podejściu do problemu skutkuje, po pierwsze, nowymi rozwiązaniami metodycznymi, po drugie zaś budzi niepokój i liczne wątpliwości w środowiskach wychowawców-praktyków. Przez lata uważano bowiem, iż proces resocjalizacji polega na korektach zaburzonych struktur i funkcji jednostek nieprzystosowanych społecznie. Brano pod uwagę przy tym głównie parametry behawioralne i osobowe. Celem natomiast owych oddziaływań była skuteczna readaptacja zaburzonych jednostek w środowisku. Tym samym zalecano możliwie wszechstronne dokonywanie usprawnień struktur i funkcji wadliwie u nich działających. Podstawowym zatem przesłaniem praktycznych wymiarów tradycyjnej, klasycznej pedagogiki resocjalizacyjnej była głębokość korekcyjnych oddziaływań. Innymi słowy, klasyczna pedagogika resocjalizacyjna upatrywała możliwości pomocy osobom nieprzystosowanym społecznie przede wszystkim

\footnotetext{
${ }^{31}$ Konopczyński, Pedagogika resocjalizacyjna, s. 58.

32 Tamże, 60.
} 
w korekcyjnie modyfikowanej zmianie ich określonych negatywnych postaw, wadliwych cech osobowości oraz dewiacyjnych form i sposobów zachowań społecznych. Nie bez znaczenia jest tutaj również wizja człowieka. W prezentowanym podejściu człowiek z natury jest raczej zły, a rolą społeczeństwa jest ujarzmić go lub izolować $\mathrm{w}$ sytuacji popełnienia przestępstwa lub stanowienia jakiegokolwiek zagrożenia społecznego. Wpływ na rozwój klasycznej myśli i pedagogiki resocjalizacyjnej miały takie koncepcje, jak: behawioryzm, podejście psychodynamiczne i niektóre koncepcje humanistyczne. Celem natomiast była korekta przekonań, postaw, nastawień i preferencji aksjologicznych. Obecnie pedagogika resocjalizacyjna jest, jak już wspominałam, coraz bardziej nauką interdyscyplinarną, tym samym odwołuje się do nowych nurtów teoretycznych i metodycznych (między innymi: teorie twórczości, kognitywizm, koncepcja resilience, dramaturgia Ervinga Goffmana) oraz kreśli nową wizję procesu resocjalizacyjnego, którą autor określa jako kreującą działalność wychowawczą. Jedną z istotniejszych zmian wydaje się akcentowanie resocjalizacyjnego znaczenia wspierania rozwoju osobowego i społecznego osób nieprzystosowanych społecznie. W nurcie tym człowiek pojmowany jest jako jednostka twórcza, kreatywna, mająca potencjał do zmiany. Proces resocjalizacji natomiast rozumiany jest jako wspomaganie rozwoju $\mathrm{z}$ wiarą $\mathrm{w}$ poprawę indywidualnego i społecznego funkcjonowania jednostek nieprzystosowanych społecznie. W tak pojętej resocjalizacji odbywają się dwa równolegle dziejące się procesy: rozwoju struktur poznawczych i twórczych oraz proces destygmatyzacji indywidualnej i społecznej w ramach zaprojektowanych oddziaływań metodycznych. Celem natomiast jest kreowanie nowych parametrów tożsamości.

Krause traktuje współczesną sytuację pedagogiki specjalnej jako pole dużego ryzyka uzgodnień paradygmatycznych. Związane jest ono $\mathrm{z}$ takimi płaszczyznami, jak choćby reprezentacją pojęciową i terminologiczną, oraz dotyczy takich zakresów rozważań, jak na przykład relacje między pojęciami a paradygmatami. Mianowicie pojęcia mogą być bezpośrednim następstwem funkcjonowania danego paradygmatu lub mogą odzwierciedlać jego zmiany. Opór wobec zmian w terminologii może oznaczać uporczywe trwanie paradygmatu zarówno w świadomości społecznej, jak i w środowisku naukowym. Autor koncentruje się głównie na takich pojęciach, jak pojęcia naznaczające, czego przykładem jest dziecko specjalnej troski czy upośledzenie umysłowe. Są to pojęcia o tyle istotne, iż generują postawy społeczne wobec pewnych zjawisk, ścieranie się i wymianę paradygmatyczną. Jacques Derrida wskazuje na język pojęć jako subtelny mechanizm wykluczania i piętnowania ${ }^{33}$. Michel Foucault natomiast pisze o językowych

${ }_{33}$ Jacques Derrida, Pismo i różnica, tłum. Krzysztof Kłosiński (Warszawa: Wydawnictwo KR 2004). 
kategoriach społecznej umowy, które służą dyscyplinowaniu społecznemu ${ }^{34}$. Transformując tę matrycę myślową rozważań na grunt pedagogiki resocjalizacyjnej, można się zastanowić, w jakim stopniu pojęcie niedostosowania społecznego w obecnej, trudno uchwytnej i zmieniającej się szybko rzeczywistości może podlegać takiej rewizji w kontekście ustawienia paradygmatycznego.

Podobnie reprezentacją paradygmatu może być diagnoza. Ona to, podobnie jak terminologia, jest silnie związana $\mathrm{z}$ panowaniem określonego paradygmatu zarówno w pedagogice, jak i w życiu społecznym. Dzięki diagnozie i jej kryteriom określane są standardy i warunki normalności oraz granice patologii. Koncentracja na odchyleniach od niej kształtuje społeczny wizerunek dewianta i paradygmat Innego. Znaczenia związane $\mathrm{z}$ paradygmatem tym utrwalane są w terminologii odmienności i wykluczenia, jednocześnie decydując o losach zdiagnozowanych. Przykładów radykalnych skutków diagnozy w konkretnym ujęciu paradygmatycznym dostarcza historia ludzkości. Krause jest zdania, iż takie powiązanie diagnozy ze społecznym paradygmatem eliminacji osobników „słabych i niedoskonałych” może stanowić realne zagrożenie dla ludzkości oraz determinować wektory polityk społecznych w danych krajach. Analogicznie w wypadku przestrzeni pedagogiki resocjalizacyjnej paradygmat eliminacji osobników niedostosowanych społecznie czy wykluczonych dosyć mocno realizowany był w ciągu wieków, czasami w sposób dosłowny, czasami zawoalowany przez politykę „wykluczania w białych rękawiczkach”. Diagnoza zatem może służyć egzekwowaniu konsekwencji przyjętych ideologii lub też kategoryzacji i dyscyplinowaniu. Użyte w niej pojęcia mogą kształtować społeczną reprezentację niedostosowania społecznego (bandyta, prostytutka, odchył, psychol, aspołeczność itp.). Ich naznaczający potencjał nabiera mocy w procesie diagnostycznym. Te specyficzne dylematy diagnostyczne są istotną częścią pola ryzyka paradygmatycznego. Przywoływany autor pisze, iż „wychodząc poza ostre kryteria naukowości T.S. Kuhna, możemy mówić o paradygmatach diagnostycznych, wchodzących nie tylko w skład pedagogiki specjalnej, ale i szerszych uzgodnień społecznych, wyznaczających w dużej mierze praktyczne (usługowe) funkcje tej dyscypliny ${ }^{35}$.

W kontekście powyższych rozważań można wskazać zależności między procesem diagnostycznym a paradygmatami pedagogiki zarówno specjalnej, jak i dalej - resocjalizacyjnej. Z jednej strony mamy do czynienia z potwierdzaniem się paradygmatu tradycjonalistycznego, $\mathrm{z}$ drugiej zaś zastępowaniem go paradygmatem humanistycznym (ulokowanie paradygmatów na linii: tradycja-rozwój). Pierwszy eksponuje się w tym, co zwykliśmy kojarzyć z diagnozami medycznymi, instrumentalnymi, technicznymi uzgodnieniami wielkości odchyleń od normy, zmierzeniem jego zakresu i wielkości w naukowych klasyfikacjach, liczbach,

${ }^{34}$ Michel Foucault, Nadzorować i karać. Narodziny więzienia, tłum. Tadeusz Komendant (Warszawa: Wydawnictwo Alatheia 1993).

${ }^{35}$ Krause, Współczesne paradygmaty, 106. 
procentach, tabelach. Ich konsekwencją są rehabilitacja i resocjalizacja korygująca, wyrównująca oraz „specjalne” działania na rzecz jednostki. Zmiany paradygmatu humanistycznego uwidaczniają się w diagnozie funkcjonalnej, która w wypadku wspomnianego nurtu nowej resocjalizacji koncentruje się na diagnozie potencjałów, zasobów, możliwości oraz takich parametrów tożsamościowych, jak pamięć, myślenie, wyobraźnia, emocje i motywacja ${ }^{36}$, celem jak najbardziej efektywnego włączenia ich $\mathrm{w}$ proces resocjalizacji. Problemy diagnozy niedostosowania społecznego ogniskują się jednak na pewnych trudnościach, z których pierwsza polega na uzgodnieniu zakresu wolności w sytuacji legislacyjnych obostrzeń związanych z zastosowaniem kar przewidzianych w aktach prawnych (Kodeks karny, Kodeks karny wykonawczy, Ustawa o postępowaniu w sprawach nieletnich) za konkretne, często zagrażające ludzkiemu zdrowiu i życiu przewinienie, czyn karalny lub przestępstwo. Kolejny problem polega na przełożeniu deklaratywnej zmiany paradygmatycznej na działania praktyczne, szczególnie w kontekstach ograniczeń systemowych.

Kolejnym polem ryzyka uzgodnień paradygmatycznych są uzgodnienia społeczne i wiedza potoczna na temat niedostosowania społecznego i osób niedostosowanych. Tutaj istotne okazują się takie zjawiska, jak stereotypizacja i wartościowanie, lecz również przeciwdziałanie stygmatyzacji. Ma to ogromne znaczenie $\mathrm{w}$ świetle propagowanych na gruncie nowej pedagogiki resocjalizacyjnej koncepcji opartych na włączaniu społeczeństwa w proces resocjalizacji, czego przykładem jest wielopasmowa koncepcja resocjalizacji z udziałem społeczeństwa Wiesława Ambrozika ${ }^{37}$. Innym jeszcze, istotnym polem ryzyka uzgodnień paradygmatycznych jest ryzyko konstruowania wiedzy o osobach niedostosowanych społecznie i co za tym idzie - sposób definiowania takich pojęć, jak: norma, patologia, inność.

Reasumując, prawdopodobnie w pedagogice resocjalizacyjnej jesteśmy w sytuacji sporu paradygmatycznego między tradycyjnym i nowoczesnym stanowiskiem wobec niedostosowania społecznego. Spór ten zapoczątkowano dyskusją o indywidualistycznym i społecznym charakterze społecznego niedostosowania. Okazało się, iż koncentracja na deficytach, defektach, brakach i osobniczych odchyleniach od normy ogranicza perspektywę rozumienia tego, czym w istocie jest niedostosowanie społeczne i jakie problemy mają ludzie nim obarczeni. Podejście to oczywiście miało wiele zalet, lecz w praktyce sprowadzało się do posługiwania się systemem dyscyplinarno-izolacyjnym, stosowania kar w dosyć tradycyjnym pojęciu oraz do reakcji społeczeństwa stanowiących odwet i zemstę.

${ }^{36}$ Marek Konopczyński, Metody twórczej resocjalizacji (Warszawa: Wydawnictwo Pedagogium oraz Wydawnictwo Naukowe PWN 2006).

${ }^{37}$ Wiesław Ambrozik, „O konieczności udziału społeczeństwa w procesie resocjalizacji przestępców”, w: Problemy współczesnej resocjalizacji, red. Lesław Pytka, Beata Maria Nowak (Warszawa: Wydawnictwo Pedagogium 2010); tenże, Pedagogika resocjalizacyjna. W stronę uspołecznienia systemu oddziaływań (Kraków: Oficyna Wydawnicza „Impuls” 2015). 
Na tym cywilizacyjnym i kulturowym etapie rozwoju, na którym się znaleźliśmy, pojawił się jednak sygnał, że osoby te potrzebują nie tylko kary, lecz i pomocy. Zrodziły się pewne zobowiązania choćby wobec rodzin, a w szczególności dzieci osób odbywających kary pozbawienia wolności, wobec osób opuszczających zakłady poprawcze czy też karne i doświadczających bezdomności, wobec nieletnich dziewcząt spodziewających się dzieci lub zostających matkami itp. Czas najwyższy, i tak rzeczywiście się dzieje, aby pedagogika resocjalizacyjna zaczęła się przyczyniać do społecznego dostrzeżenia tych ludzi i ich rodzin, a co za tym idzie - podejmowała próby wyprowadzania ich ze środowiskowych enklaw biedy, gett ubóstwa (także moralnego) i przestrzeni porzucenia. Żyjemy w okresie rozpaczliwej walki o prawa człowieka, również osadzonego i jego rodziny, w szczególności dzieci. Pojawiają się programy, w których priorytetami jest zapewnienie dzieciom kontaktu z rodzicami przebywającymi w izolacji więziennej. Występują również programy pracy z osadzonymi nieletnimi i ich rodzinami, których priorytetem jest odbudowanie więzi. Istnieją programy uczące młode, nieletnie matki tworzenia więzi ze swoimi nowo narodzonymi dziećmi. Więź międzyludzka bowiem jest najpotężniejszym czynnikiem chroniącym przed zachowaniem ryzykownym. To czynnik leczący zarówno na poziomie rodzinnym, jak i lokalnym. Sukcesem tutaj staje się budowanie systemu wsparcia dla osób powracających z izolacji do swoich wspólnot rodzinnych i lokalnych. Rodzi się też zobowiązanie społeczeństwa wobec niedostosowanych społecznie.

To, co istotne, otwiera się także miejsce na debatę na temat form i metod pracy z osobami niedostosowanymi społecznie, wykluczonymi, zdemoralizowanymi. W tym kontekście należy docenić wysiłki niektórych teoretyków pedagogiki resocjalizacyjnej, by wdrażać zmiany paradygmatyczne. Wobec ograniczonych czasami możliwości wprowadzania przez pedagogów resocjalizacyjnych w życie nowych, systemowych rozwiązań zostały one wprowadzone na poziomie teoretycznym, a do dorobku najważniejszych autorów w tym zakresie sięgam w niniejszym tekście. Skutki szczegółowych uzgodnień paradygmatycznych widoczne są w pedagogice resocjalizacyjnej, choć trudno precyzyjnie określić, w którym dokładnie miejscu zmiany paradygmatycznej jesteśmy i jaki jest stopień dominacji nowego paradygmatu. Niezależnie jednak od tego, wartość paradygmatów w pedagogice resocjalizacyjnej jest konieczna dla dyscyplinarnego samookreślenia się, poszukiwania tożsamości naukowej i wyznaczania kierunków zmian i rozwoju.

Streszczenie: Artykuł ma na celu zaprezentowanie refleksji na temat zmiany w myśleniu o procesie resocjalizacji i osobach niedostosowanych społecznie w świetle zmian paradygmatów w polskiej myśli resocjalizacyjnej. Autorka przedstawia dwa nurty w pedagogice resocjalizacyjnej: tradycyjną, klasyczną resocjalizację oraz nurt „nowej resocjalizacji” w świetle sytuacji zmiany paradygmatu na gruncie myślenia resocjalizacji osób niedostosowanych społecznie. Pociąga to za sobą konsekwencje metodyczne w podejściu do osób niedostosowanych i przyczynia się do rewizji odpowiedzi na pytanie: „jak resocjalizować?”. 
Słowa kluczowe: proces resocjalizacji, osoby niedostosowane społecznie, paradygmat, „nowa resocjalizacja”, polska myśl resocjalizacyjna

\section{Bibliografia}

Alternatywy myślenia o edukacji, red. Zbigniew Kwieciński. Warszawa: Instytut Badań Edukacyjnych, 2000.

Ambrozik, Wiesław. „O konieczności udziału społeczeństwa w procesie resocjalizacji przestępców”. W: Problemy współczesnej resocjalizacji, red. Lesław Pytka, Beata Maria Nowak. Warszawa: Wydawnictwo Pedagogium, 2010.

Ambrozik, Wiesław. Pedagogika resocjalizacyjna. W stronę uspołecznienia systemu oddziaływań. Kraków: Oficyna Wydawnicza „Impuls”, 2015.

Derrida, Jacques. Pismo i różnica, tłum. Krzysztof Kłosiński. Warszawa: Wydawnictwo KR, 2004.

Foucault, Michel. Nadzorować i karać. Narodziny więzienia, tłum. Tadeusz Komendant. Warszawa: Wydawnictwo Alatheia, 1993.

Grzegorzewska, Maria. Pedagogika specjalna. Warszawa: Wyższa Szkoła Pedagogiki Specjalnej im. M. Grzegorzewskiej w Warszawie, 1964.

Konopczyński, Marek. Kryzys resocjalizacji czy(li) sukces działań pozornych. Refleksje wokół polskiej rzeczywistości resocjalizacyjnej. Warszawa: Wydawnictwo Pedagogium, 2013.

Konopczyński, Marek. Metody twórczej resocjalizacji. Warszawa: Wydawnictwo Pedagogium oraz Wydawnictwo Naukowe PWN, 2006.

Konopczyński, Marek. Pedagogika resocjalizacyjna w stronę działań kreujących. Kraków: Oficyna Wydawnicza „Impuls”, 2014.

Krause, Amadeusz. Wspótczesne paradygmaty pedagogiki specjalnej. Kraków: Oficyna Wydawnicza „Impuls”, 2010.

Kuhn, Thomas S. Struktura rewolucji naukowych, tłum. Helena Ostromęcka. Warszawa: Wydawnictwo Aletheia, 2001.

Kwieciński, Zbigniew. „Mimikra czy sternik? Dramat pedagogiki w sytuacji przesilenia formacyjnego". W: tegoż, Tropy - ślady - próby. Studia i szkice z pedagogiki pogranicza. Poznań-Olsztyn: Wydawnictwo Edytor, 2000.

Paulston, Rolland G. „Pedagogika porównawcza jako pole nakreślenia konceptualnych map teorii i paradygmatów". W: Alternatywy myślenia o edukacji, red. Z. Kwieciński. Warszawa: Instytut Badań Edukacyjnych, 2000.

Pytanie - dialog - wychowanie, red. Joanna Rutkowiak. Warszawa: Wydawnictwo Naukowe PWN, 2009.

Riessman, Frank, David Carroll. Nowa definicja samopomocy. Polityka i praktyka, tłum. Helena Grzegołowska-Klarkowska. Warszawa: Państwowa Agencja Rozwiązywania Problemów Alkoholowych, 2000.

Rubacha, Krzysztof. „Budowanie teorii pedagogicznych”. W: Pedagogika. Podręcznik akademicki, t. 1, red. Zbigniew Kwieciński, Bogusław Śliwerski, Warszawa: Wydawnictwo PWN, 2003.

Rutkowiak, Joanna. „Wielość paradygmatów dydaktyki a wspólny mianownik realności życia. Ku pytaniom o przekłady międzyparadygmatyczne”. W: Paradygmaty współczesnej dydaktyki, red. Lucyna Hurło, Dorota Klus-Stańska, Majka Łojko. Kraków: Oficyna Wydawnicza „Impuls”, 2009.

Sięgień, Anna. „Paradygmat”. W: Encyklopedia pedagogiczna XXI wieku, t. 4, red. T. Pilch. Warszawa: Wydawnictwo Akademickie Żak, 2005. 
Szkudlarek, Tomasz. „Obiektywizm i subiektywizm pedagogiczny a całościowe myślenie o wychowaniu". W: Pytanie - dialog - wychowanie, red. J. Rutkowiak. Warszawa: Wydawnictwo Naukowe PWN, 2009.

Śliwerski, Bogusław. Współczesna myśl pedagogiczna. Znaczenia, klasyfikacje, badania. Kraków: Oficyna Wydawnicza „Impuls”, 2009.

Witkowski, Lech. Edukacja i humanistyka. Nowe konteksty dla nowoczesnych nauczycieli, t. 2. Warszawa: Instytut Badań Edukacyjnych, 2007.

Witkowski, Lech. Między pedagogika, filozofia i kulturą. Studia, eseje, szkice, t. 3. Warszawa: Instytut Badań Edukacyjnych, 2007. 